\title{
CHARACTERIZATION OF HAZELNUT MILK FERMENTED BY LACTOBACILLUS DELBRUECKII SUBSP. BULGARICUS AND STREPTOCOCCUS THERMOPHILUS
}

\author{
Ertan Ermiş ${ }^{1 *}$, Rabia Güneş ${ }^{1}$, İnci Zent ${ }^{1}$, Muhammed Yusuf Çağlar ${ }^{1}$, \\ Mustafa Tahsin Y1lmaz \\ ${ }^{1}$ İstanbul Sabahattin Zaim University, Faculty of Engineering and Natural Sciences, Food Engineering \\ Department, İstanbul, Turkey \\ ${ }^{2}$ Yildız Technical University, Chemical and Metallurgical Engineering Faculty, Food Engineering Department, \\ İstanbul, Turkey
}

Received / Geliş: 18.01.2018; Accepted / Kabul: 17.07.2018; Published online / Online bask1: 07.08.2018

Ermiş, E., Güneş, R., Zent, İ., Çağlar, M.Y., Yılmaz, M.T. (2018). Characterization of hazelnut milk fermented by Lactobacillus delbrueckii subsp. bulgaricus and Streptococcus thermophilus. GIDA (2018) 43 (4): 677-686 doi: 10.15237/gida.GD18022

\begin{abstract}
Raw hazelnut milk were used to develop new plant-based fermented product using commercial starter mix containing Lactobacillus delbrueckii subsp. bulgaricus and Streptococcus thermophilus strains in order to address the current demand for health promoting and functional plant-based dairy-like products. The $\mathrm{pH}$, titratable acidity (TA), serum separation (SS), protein content, fat content and ash content of fermented product were found to be 4.95, $1.25 \mathrm{~g}$ lactic acid/ $100 \mathrm{~mL}, 28.00 \%, 2.60 \%, 7.03 \%$ and $0.66 \%$, respectively. Fermented hazelnut milk demonstrated non-Newtonian pseudoplastic flow behavior and it's structure was more predominantly elastic than viscous. Sensory analysis showed that some attributes of fermented hazelnut milk such as color, aroma, consistency, typical yoghurt odor and overall acceptability were less appreciated than Ayran (commercial cow milk yogurt drink) whereas some other attributes were found as satisfying.

Keywords: Hazelnut, fermentation, functional foods, foods of plant origin, Ayran

\section{LACTOBACILLUS DELBRUECKII SUBSP. BULGARICUS VE STREPTOCOCCUS THERMOPHILUS ILLE FERMENTE EDİLMİŞ FINDIK SÜTÜNÜN KARAKTERİZASYONU}

ÖZ

Ham findıktan Lactobacillus delbrueckii subsp. bulgaricus ve Streptococcus thermophilus ticari suşları kullanılarak sağlığ1 teşvik edici, fonksiyonel özellikte fermente bir ürün elde edilmiştir. İlk aşamada, ultrasonikasyon uygulaması ile findık sütünün homojenizasyonu sağlanmıştır. Elde edilen fermente ürününün $\mathrm{pH}$, titre edilebilir asitlik, serum ayrilma kapasitesi, protein içeriği, yağ içeriği ve kül içeriği sırasiyla 4.95, $1.25 \mathrm{~g}$ laktik asit $/ 100 \mathrm{~mL}, \% 28.00, \% 2.60, \% 7.03$ ve $\% 0.66$ olarak bulunmuştur. Reolojik analizlerden elde edilen veriler fermente findık sütünün Newtonian olmayan psödoplastik akış davranışı sergilediğini ve yapısının viskozdan daha elastik olduğunu göstermiştir. Duyusal analiz, renk, aroma, tipik yoğurt kokusu ve genel kabul edilebilirlik gibi fermente findık sütünün bazı niteliklerinin Ayran'dan daha az takdir edildiğini, ancak diğer bazı özelliklerin tatmin edici olduğu sonucuna varılmıştır.

Anahtar kelimeler: Findık, fermentasyon, fonksiyonel g1dalar, bitki esasli gidalar, Ayran

${ }^{*}$ Corresponding Author / Yazışmalardan Sorumlu Yazar

$\triangle$ ertan.ermis@gmail.com @ (+90) 2126929722

县 $(+90) 2126938229$ 


\section{INTRODUCTION}

The consumer demand for alternatives to cow's milk increased due to the rise of health problems such as lactose intolerance and cow's milk allergy. In addition, avoiding dairy products has been a lifestyle including vegetarian and vegan diets and based on health concerns including antibiotic residues and cholesterol and based on diet preferences or based on ethical considerations (Jeske et al. 2017). The total sales of plant-based milk substitute in EU market has been reached \$1.9 billion in 2015 (Jeske et al. 2017). Hazelnut milk (HM) which is prepared by grounding the hazelnut in water, homogenizing and filtering could supply almost the same potential health benefits as whole hazelnuts (Bernat et al. 2014, 2015; Jeske et al. 2017). HM may be used in the production of fermented products as substitute to bovine milk products to contribute to the health benefits of the products and possibly to be alternative to animal milk products in lactointolerant and vegetarian consumers (Bernat et al. 2014).

Hazelnuts are extensively used by food industry to produce products including ice-cream and dairy, baking, confectionery, candy and chocolate products. They are mostly used in various products to give taste and aroma (Simsek and Aykut 2007). Hazelnuts play a crucial role in human health and nutrition due to their composition of protein, carbohydrates, lipids, vitamins, dietary fibres, phenolic compounds, tocopherols, minerals, phytosterols and squalene, and it is a potential energy source $(600-650 \mathrm{kcal}$ in 100 grams) (Alasalvar et al. 2003; Köksal et al. 2006). HM contains monounsaturated fatty acids (i.e. oleic acid) and phytosterols (i.e. $\beta$-sitosterol) and antioxidant compounds (Lainas et al. 2016). Given the combination of its health-promoting properties and nutritional composition, hazelnut could be the raw material to manufacture a new generation of plant based fermented milk products.

In this paper, it was aimed to produce a dairy-like fermented product for the ones sensitive to bovine products. For this purpose, HM was produced and fermented by commercial yogurt starter culture Streptococcus thermophilus and Lactobacillus delbrueckii subsp. bulgaricus. In addition to analysis of microstructure and chemical composition, rheological behavior and sersory attributes were investigated. Comparison of the data obtained to those of Ayran was also given.

\section{MATERIALS AND METHODS}

All chemicals and solvents (analytical grade) were purchased from Merck (Darmstad, Germany). FAME (fatty acid methyl esters) mix was purchased from Sigma-Aldrich (St. Louis, MO, USA).

\section{Preparation of hazelnut milk}

Hazelnut raw kernels were obtained from a local market in İstanbul, Turkey. The methods found in the literature (Al-nabulsi et al. 2014; Bernat et al. 2014) were modified and used for production of HM. For this purpose, unroasted hazelnut kernels were grounded and soaked in distilled water and homogenized for 2 minutes by a laboratory homogenizer (WiseTis HG-15A, witeg Labortechnik GmbH, Wertheim, Germany) after filtered through two folded cloth filter. Then, the mix was further homogenized by an ultrasound homogenizer (Hielscher UP400S, Teltow, Germany) at $100 \mathrm{~W}$ and $20 \mathrm{kHz}$ for 10 minutes to achieve homogeneous dispersion of oil droplets (Ertugay et al. 2004).

\section{Colloidal stability of HM}

Colloidal stability of ultrasound-homogenized and non-homogenized (control) HM samples was determined through the phase separation analysis during 7 days of storage time at $4{ }^{\circ} \mathrm{C}$. For this purpose, about $15 \mathrm{~g}$ of $\mathrm{HM}$ was poured into 16 $\mathrm{mm}$ diameter of glass tubes and the degree of the separated phases was visually evaluated after ultrasonication. Additionally, the colloidal structure of the HM before and after ultrasound homogenization was evaluated using a light camera (Wu et al. 2000)

\section{Fermentation process}

The activated starter culture mix (Streptococcus thermophilus and Lactobacillus delbrueckii subsp. bulgaricus) in liquid form was obtained from a milk processing company (Atesoglu Milk Products 
Co., Istanbul, Turkey). The activated commercial culture mix containing $S$. thermophilus and $L$. delbrueckii subsp. bulgaricus cells were enumerated on M17 agar medium ( $\mathrm{pH}$ 6.9) and on acidified MRS agar medium ( $\mathrm{pH}$ 5.4), respectively (Ghoddusi and Robinson 1996; Ashraf and Shah 2011). For this purpose, $25 \mathrm{ml}$ starter mix was poured into $225 \mathrm{ml}$ sterile peptone diluents $(0.1 \mathrm{~g} / \mathrm{L})$. Appropriate dilutions were made by adding $1 \mathrm{~mL}$ of aliquot to $9 \mathrm{~mL}$ of sterile peptone diluent. Pour plate technique was carried out for enumeration of the cells. S. thermopbilus and $L$. delbrueckii subsp. bulgaricus were incubated $37^{\circ} \mathrm{C}$ for $48 \mathrm{~h}$. Plates containing 20 to 300 colonies were enumerated, and the counts were expressed as $\mathrm{CFU} / \mathrm{mL}$. Additionally, total number of cells was determined using a Thoma cell chamber (Glaswarenfabrik Karl Hecht GmbH \& Co KG, Germany) for rapid enumeration prior to inoculation (Pleissner et al. 2016). Counting the colonies on respective mediums showed that the commercial inoculum contained around $8 \log$ $\mathrm{CFU} / \mathrm{mL} \mathrm{L}$. delbrueckii subsp. bulgaricus and around $9 \log \mathrm{CFU} / \mathrm{mL} S$. thermophilus.

As suggested previously, HM samples were enriched with $1.5 \%(\mathrm{w} / \mathrm{w})$ glucose solution prior to the fermentation process in order to achieve the growth of the mixed culture used, which also resulted in acidification (Bernat et al. 2014). The liquid starter mix was inoculated into $\mathrm{HM}$ at a rate of $1 \%(\mathrm{v} / \mathrm{v})$. The inoculated HM samples were incubated at $45{ }^{\circ} \mathrm{C}$ and the fermentation was stopped at $\mathrm{pH}$ 4.6. The fermented hazelnut milk (FHM) samples were immediately cooled and stored at $4{ }^{\circ} \mathrm{C}$ for 12 hours prior to analyses.

\section{Chemical properties and proximate analyses}

Analyses of moisture, total nitrogen (protein) and fat content in HM and FHM samples were conducted based on the methods as outlined, AOAC 16.006, AOAC 958.48, and AOAC 945.16, respectively (Horwitz, 2000). The ash content was determined by incineration in an electric muffle furnace at $550{ }^{\circ} \mathrm{C}$.

The $\mathrm{pH}$ values were measured at $25^{\circ} \mathrm{C}$ using a calibrated pH meter (Hanna HI2211, Germany). The AOAC standard method AOAC 947.05
(AOAC 2000) was used to determine the titratable acidity in samples (Yasmin et al. 2015). $25 \mathrm{~mL}$ sample was titrated against $0.1 \mathrm{~mol} / \mathrm{L} \mathrm{NaOH}$ solution until $\mathrm{pH} 8.3$ remain stable for $10 \mathrm{~s}$ using phenolphthalein as indicator and the results were expressed as grams of lactic acid equivalent per $100 \mathrm{ml}$ of the sample.

Fatty acid composition of FHM samples was determined by using GC (Agilent 6890 GC) equipped with HP-88 column (100 m x $0.25 \mathrm{~mm}$ ID $\times 0.2 \mu \mathrm{m})$ and FID. The methyl esters of the fatty acids (FAME) were prepared according to AOCS Official Method Ce 1h-05 (AOCS 2009). $0.1 \mathrm{gr}$ of sample was mixed with $10 \mathrm{ml}$ of $\mathrm{n}$ Hexane and vortexed for 30 seconds with a vortex mixer. 100 microliters of $2 \mathrm{~N}$ potassium hydroxide (prepared in methyl alcohol) was added and mixed for 30 seconds using a vortex mixer. After centrifugation of whole mix, 1-2 $\mathrm{ml}$ of the liquid phase was poured into a vial and injected into GC-FID equipped with auto sampler (injection volume: $1 \mu \mathrm{L}$ ). Temperature and oven program of the device were as follows: Inlet temperature: $250{ }^{\circ} \mathrm{C}$; Injection volume: $1 \mu \mathrm{l}$; Split Ratio: 1/50; Carrier gas: Helium; Pressure flow: 2 $\mathrm{mL} / \mathrm{min}$; Oven Temperature: $120{ }^{\circ} \mathrm{C}, 1 \mathrm{~min}$, $10^{\circ} \mathrm{C} / \mathrm{min}$ to $175^{\circ} \mathrm{C}, 5^{\circ} \mathrm{C} / \mathrm{min}$ to $210^{\circ} \mathrm{C}, 5 \mathrm{~min}$ $5^{\circ} \mathrm{C} / \mathrm{min} 230^{\circ} \mathrm{C}, 5 \mathrm{~min}$; Detector temperature: $280{ }^{\circ} \mathrm{C}$; Detector gases. Hydrogen: $40 \mathrm{~mL} / \mathrm{min}$, Air: $450 \mathrm{~mL} / \mathrm{min}$, Helium: $30 \mathrm{~mL} / \mathrm{min}$.

\section{Serum separation}

For the analysis of serum separation (SS) of FHM, the method as outlined by Lucey et al. (1999) was modified and used. Samples were placed in $50 \mathrm{~mL}$ graduated cylinders and stored at $4{ }^{\circ} \mathrm{C}$. The volume of the separated serum at the top was read after storage for 10 days. The results were expressed as $\mathrm{mL}$ serum separated per $50 \mathrm{~mL}$ of the sample.

\section{Rheological properties \\ Steady-state shear properties}

The rheological behavior was characterized using a rheometer (Anton Paar, MCR 302, Austria) with a probe using a cone-plate configuration (cone diameter $50 \mathrm{~mm}$, angle $4^{\circ}$, gap size $0.140 \mathrm{~mm}$ ). The shear stress $(\sigma)$ was measured as a function of 
shear rate $(\gamma)$ from 1 to $100 \mathrm{~s}^{-1}$ at $25^{\circ} \mathrm{C} .1 .0 \mathrm{ml}$ sample was placed between cone and plate and the measurement was started immediately. Each measurement was replicated three times on three different samples (each $1 \mathrm{ml}$ ) from the same sample with two repetitions. The HerschelBulkey model (Eq. 1) was fitted to the experimental points to determine the flow behavior index $(n)$, consistency index $(K)$ and yield stress $\left(\sigma_{0}\right)$ using a non-linear procedure. Apparent viscosities were calculated at $50 \mathrm{~s}^{-1}$, since the shear rates generated in mouth when food is being chewed and swallowed are between 10 and $100 \mathrm{~s}^{-}$ 1 (McDorman 2009).

$$
\sigma=\sigma_{0}+K(X)^{n}
$$

\section{Viscoelastic properties}

The amplitude sweep test was performed at $1 \mathrm{~Hz}$ in the strain range of $0.1-100 \%$ to determine the linear viscoelastic region (LVR). Frequency sweep test was performed at $1 \%$ strain (determined by amplitude sweep test) over a frequency range of $0.1-10 \mathrm{~Hz}$ at $25^{\circ} \mathrm{C}$. Each measurement was repeated three times with three replications. The viscoelastic parameters of $G^{\prime}$ (elastic or storage modulus) (Pa) and $G^{\prime \prime}$ (viscous or loss modulus) $(\mathrm{Pa})$ were calculated using the following equations (Steffe 1996).

$$
\begin{aligned}
& G^{\prime}=K^{\prime}(\omega)^{n^{\prime}} \\
& G^{\prime \prime}=K^{\prime \prime}(\omega)^{n^{\prime \prime}}
\end{aligned}
$$

where $K, \omega, n$ are the consistency index $\left(\mathrm{Pa} \cdot \mathrm{s}^{\mathrm{n}}\right)$, oscillatory frequency and the flow behavior index (dimensionless) respectively,

\section{Sensory properties}

Sensory analysis (hedonic test) was conducted as described by (He and Hekmat 2015) with some modifications. Sensory evaluation was performed in open sitting in a room where the temperature was $25{ }^{\circ} \mathrm{C}$. Twenty panelists (fourth year food engineering students) were randomly selected. The panelists were trained by giving them the explanation of the score sheet and method of scoring as well as the information about the definition of quality attributes selected for sensory evaluation (Routray and Mishra 2012). The sensory test included color, taste, mouthfeel, consistency, aroma, acidity, typical yogurt odor and overall acceptability. FHM was firstly served followed by the commercial full fat Ayran. They evaluated the samples using a 5 -points hedonic scale. The scores were assigned from 1 (extremely dislike) to 5 (extremely like).

\section{Statistical analysis}

One way analysis of variance (ANOVA) was applied to determine whether any of the differences between the means are statistically significant. Tukey method was used to declare significant differences at $95 \%$ confidence $(P<0.05)$. Statistical analyses were performed using Minitab version 17.3.1 (Minitab, Inc., State College PA, USA).

\section{RESULTS AND DISCUSSION \\ Proximate composition and chemical properties}

Proximate composition (moisture, protein, fat and ash), chemical properties ( $\mathrm{pH}$ and total acidity) of hazelnut milk (HM), Ayran and fermented hazelnut milk (FHM) are presented in Table 1. HM had remarkable higher content of fat and slightly lower content of protein in comparison with those of a standardized cow milk (3.2 and $3.3 \mathrm{~g} / 100 \mathrm{~mL}$ of fat and protein, respectively) (Wijesinha and Burlingame 2013). The findings of this study were comparable with those reported in the literature (Bernat et al. 2015; Ilyasoğlu et al. 2015). There were no huge differences between the properties of HM and FHM except for large significant differences in their $\mathrm{pH}$ and total acidity values $(P=0.000)$. The reason to this change is attributed to decreasing the $\mathrm{pH}$ value and increasing titratable acidity during fermentation where lactic acid bacteria used glucose to form lactic acid and $\mathrm{CO}_{2}$ gas. Small significant differences were also obtained in moisture and fat contents $(P=0.039$ and $P=0.012$, respectively). However significant differences $(P<0.05)$ were obtained between the properties of Ayran and FHM. The results of this work indicated that SS of FHM was lower than that of Ayran (Table 1). This might be attributed to the differences in $\mathrm{pH}$, titratable acidity and properties of protein matrix which are important factors affecting SS (Gursoy et al. 2016). 
Table 1. Characteristics of HM and FHM ( $\mathrm{n}=3)$, (Mean \pm sd)

\begin{tabular}{|c|c|c|c|c|c|}
\hline Characteristics & $\mathrm{HM}$ & Ayrand $^{d}$ & FHM & $\begin{array}{c}\text { Level of } \\
\text { significance } \\
\text { (Ayran-FHM) }\end{array}$ & $\begin{array}{c}\text { Difference } \\
(\%) \\
\text { for Ayran } \\
\end{array}$ \\
\hline \multicolumn{6}{|l|}{ Proximate composition } \\
\hline Dry matterb & $11.63 \pm 0.25$ & $7.75 \pm 0.83$ & $12.56 \pm 0.47$ & $*(P=0.001)$ & 5.21 \\
\hline Protein ${ }^{b}$ & $2.34 \pm 0.09$ & $1.14 \pm 0.34$ & $2.60 \pm 0.20$ & $*(P=0.003)$ & -128.07 \\
\hline $\mathrm{Fat}^{\mathrm{b}}$ & $7.48 \pm 0.10$ & $2.09 \pm 0.34$ & $7.03 \pm 0.15$ & $*(P=0.000)$ & -236.52 \\
\hline Ash b & $0.54 \pm 0.07$ & $0.48 \pm 0.04$ & $0.66 \pm 0.04$ & $*(P=0.006)$ & -36.80 \\
\hline \multicolumn{6}{|l|}{ Chemical properties } \\
\hline $\mathrm{pH}$ & $6.93 \pm 0.03$ & $4.48 \pm 0.02$ & $4.95 \pm 0.02$ & $*(P=0.000)$ & -10.41 \\
\hline Titratable acidityc & $0.33 \pm 0.03$ & $0.82 \pm 0.10$ & $1.25 \pm 0.05$ & $*(P=0.003)$ & -52.44 \\
\hline $\mathrm{SS}(\mathrm{mL} / 50 \mathrm{~mL})$ & - & $28.50 \pm 0.10$ & $14.00 \pm 0.42$ & $*(P=0.000)$ & 50.87 \\
\hline
\end{tabular}

${ }^{a}$ Difference (\%) Ayran $=[($ Ayran value - FHM value $) /$ Ayran value $] \times 100$,

b $\mathrm{g} / 100 \mathrm{~g}$ product,

${ }^{c} \mathrm{~g}$ lactic acid $/ 100 \mathrm{~mL}$,

d(Özünlü and Koçak 2010; Gursoy et al. 2016)

* significantly different $(P<0.05)$

HM: hazelnut milk, FHM: fermented hazelnut milk, SS: serum separation

The results of this study revealed that FHM contained monounsaturated and polyunsaturated fatty acids in its lipid fraction (Table 2). As it can be seen in Table 2, FHM contained around $89 \mathrm{~g}$ mono and poly-unsaturated fatty acids and $11 \mathrm{~g}$ saturated fatty acids per $100 \mathrm{~g}$ of lipid fraction. The oleic acid concentration (approximately $81 \%$ ) in FHM was similar to the one reported previously (Ilyasoğlu et al. 2015). They found around $85 \%$ oleic acid in yogurt -like product from hazelnut slurry. They also reported the linoleic acid and palmitic acid concentrations as approximately $7 \%$ and $5 \%$, which agrees with the data obtained in this study (around $7.1 \%$ and $6.8 \%)$.

Table 2. Fatty acid composition of FHM $(\%)(n=3)($ Mean \pm sd)

\begin{tabular}{lc}
\hline Fatty Acid Composition & $\%$ \\
\hline Lauric Acid (C12:0) & $0.25 \pm 0.12$ \\
Miristic Acid (C14:0) & $0.21 \pm 0.05$ \\
Miristoleic Acid (C14:1 Cis-9) & $0.12 \pm 0.00$ \\
Pentadecenoic Acid (C15:1 Cis-10) & $0.30 \pm 0.06$ \\
Palmitic Acid (C16:0) & $6.76 \pm 0.56$ \\
Palmitoleic Acid (C16:1 Cis-9) & $0.17 \pm 0.01$ \\
Margaric Acid (C17:0) & $0.06 \pm 0.00$ \\
Heptadecenoic Acid (C17:1 Cis-10) & $0.60 \pm 0.75$ \\
Stearic Acid (C18:0) & $3.11 \pm 0.11$ \\
Oleic Acid (C18:1 Cis-9) & $80.97 \pm 0.15$ \\
Linoleic Acid (C18:2 Cis-9.12) & $7.07 \pm 0.52$ \\
Linolenic Acid (C18:3 Cis-6.9.12) & $0.20 \pm 0.12$ \\
Eicosenoic Acid (C20:1 Cis-11) & $0.39 \pm 0.54$ \\
§- Linoleic Acid (C18:3 Cis-9.12.15) & $0.12 \pm 0.01$ \\
\hline
\end{tabular}

FHM: fermented hazelnut milk 


\section{Colloidal stabilization of $\mathrm{HM}$}

The ultrasound homogenization had significant effect on the size distribution of plydispersed fat droplets as the size of bigger fat droplets was reduced almost 10 folds. These findings are in agreement with those reported previously (O’Sullivan et al. 2015).

\section{Rheological properties of FHM \\ Steady-state shear properties}

In this study, rheological properties of FHM (Fig. 1) was determined after fermentation of HM, therefore, FHM was characterized in terms of steady and dynamic shear properties. The change of shear stress versus the shear rate shows that the FHM was a non-Newtonian pseudoplastic flow behavior with a beginning resistance against the flow, as revealed by the calculated yield stress. This behavior of FHM is in agreement with the findings of previous studies (Koksoy and Kilic 2003; Janhøj et al. 2008; Kök 2010). HerschelBulkley model parameters of FHM, R', the yield stress, consistency coefficient and flow behavior index values were found to be $0.99,0.21,0.06$ and 0.57 respectively, the $R^{2}$ value was very close to 1 , which means that the Herschel-Bulkley function well fitted to the flow behavior of FHM.

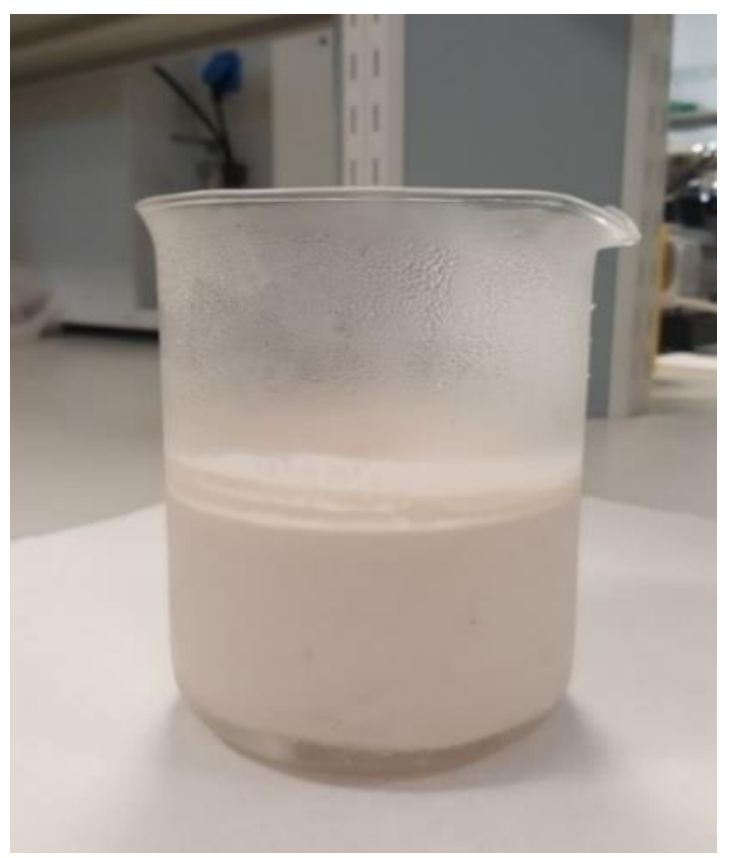

Figure 1. A view of fermented hazelnut milk

\section{Viscoelastic properties}

The viscoelastic properties of the FHM were measured under $0.5 \%$ strain using the frequency screening test. The magnitude of the energy stored in the material or recoverable per cycle of deformation is called as storage (or elastic) modulus $G^{\prime}$, while the energy that is lost at viscous dissipation per cycle of deformation is mentioned as the loss (or viscous) modulus $G^{\prime \prime}$. Therefore, all the energy is stored in a perfectly elastic solid, which results in zero loss modulus and the stress and strain will be in phase whereas all the energy is dissipated as heat in a liquid with no elastic properties; $G^{\prime}$ is zero and the stress and strain will be out of phase by $-90^{\circ}$ (Sharoba et al. 2005).

The changes in storage modulus $\left(G^{\prime}\right)$, loss modulus $\left(G^{\prime \prime}\right)$ and and complex viscosity $\left(\eta^{*}\right)$ as a function of frequency for FHM is presented in Table 3. The magnitudes of $G^{\prime}$ and $G^{\prime \prime}$ increased with increase in frequency, revealing viscoelastic nature of FHM. Plots of frequency versus $G^{\prime}$ and $G^{\prime \prime}$ dynamic rheological data were subjected to non-linear regression and the magnitudes of intercepts, slopes and $R^{2}$ values were studied (Table 3). The storage and loss moduli and the complex viscosity plotted versus frequency indicated that the viscoelastic behavior of the FHM could be well described by Eqs. (2) and (3) with high determination coefficients (0.9950.988).

Table 3. Values for the power law model for storage $\left(G^{\prime}\right)$ and loss $\left(G^{\prime \prime}\right)$ modules of fermented hazelnut milk (n=3) (mean \pm sd)

\begin{tabular}{|c|c|c|c|}
\hline \multicolumn{2}{|c|}{$G^{\prime}=K^{\prime}(\omega)^{n^{\prime}}$} & \multicolumn{2}{|c|}{$G^{\prime \prime}=K^{\prime \prime}(\omega) r^{\prime \prime}$} \\
\hline$K^{\prime}$ & $2.099 \pm 0.110$ & $K^{\prime \prime}$ & $0.390 \pm 0.025$ \\
\hline$n^{\prime}$ & $0.245 \pm 0.014$ & $n^{\prime \prime}$ & $0.463 \pm 0.013$ \\
\hline$R^{2}$ & $0.995 \pm 0.006$ & $R^{2}$ & $0.988 \pm 0.001$ \\
\hline
\end{tabular}

As far as the structure point of view of FHM was concerned, for true gels $\left(G^{\prime}, G^{\prime \prime}\right)$ versus $\omega$ plots have zero slope; however, positive slopes show that the storage (elastic) modulus $\left(G^{\prime}\right)$ is greater than the loss (viscous) modulus $\left(G^{\prime \prime}\right)$ over a whole frequency ranges of $\omega$ studied for weak gels and highly concentrated dispersions (Ross-Murphy 1984). The dynamic oscillatory test data in this 
study revealed that the slopes were positive $\left(n^{\prime}=\right.$ $\left.0.245 ; n^{\prime \prime}=0.463\right)$ and almost parallel to each other and $G^{\prime}\left(K^{\prime}=2.099\right)$ was higher than that of $G^{\prime \prime}\left(K^{\prime \prime}=0.390\right)\left(G^{\prime}>G^{\prime \prime}\right)$ without exhibiting any cross point of $G^{\prime}$ and $G^{\prime \prime}$ along the whole frequency range studied (Fig. 2). These results suggest that the FHM was more predominantly elastic than viscous. Similar behavior has been reported for some food samples such as pulps, purees, juices and concentrates (Augusto et al. 2012). Ramchandran and Shah (2009) investigated textural and rheological properties of low-fat yogurt and they report that $G$ " was lower than $G^{\prime}$ for the samples indicating that they exhibited characteristics typical of a weak viscoelastic gel structure. Shirkhani et al. (2015) studied the rheological behavior of fermented milk drink and they reported that $G^{\prime}$ values were greater than $G^{\prime \prime}\left(G^{\prime}>G^{\prime \prime}\right)$, indicating the presence of gel-like structure. Similarly, Zhou (2018) found that $G^{\prime}$ values were greater than $G^{\prime \prime}\left(G^{\prime}>G^{\prime \prime}\right)$ for drinking yogurt. However, according to Kök (2010)'s findings, yogurt drink samples showed non-Newtonian behaviour and viscous component predominated over elastic modulus $\left(G^{\prime \prime}>G^{\prime}\right)$. The reason might be attributed to the variation in composition and structure of the samples studied as well as degree of homogenization.

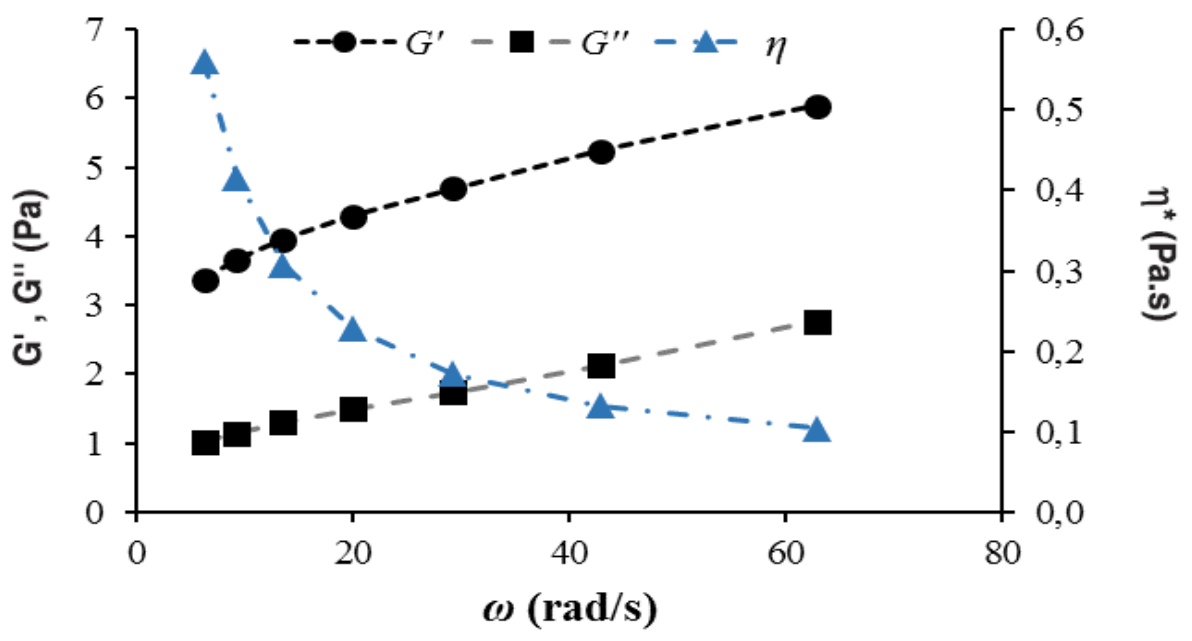

Figure 2. Mechanical spectra of fermented hazelnut milk

In the description of viscoelastic behavior, loss tangent $\left(G^{\prime \prime} / G^{\prime}\right)$ is also used to indicate if the material of concern would have elastic or viscous properties. In the case of FHM, the larger the tan $\delta$ value, the more easily the FHM flows. The loss tangent values showed a predominantly elastic behavior $\left(\tan \delta<1\right.$ or $\left.G^{\prime}>G^{\prime \prime}\right)$ for FHM over the increased frequency, which can be attributed to the existence of a phase lag between the input sinusoidal signal and the response one (Muñoz et al. 2007).

\section{Sensory properties}

The sensory attributes of FHM were compared with those of commercial full fat Ayran based on the hedonic scale. According to results given in Table 4, the taste attribute of FHM was scored very close to that of Ayran $(P=0.906)$ whereas the consistency of FHM was evaluated as less consistent $(P=0.027)$. Acidity and mouthfeel attributes got similar scores with slight differences from the panelists $(P=0.960$ and $P=0.313$, respectively). According to panelists' evaluation, the score of overall acceptability attribute of FHM showed significant difference compared to that of Ayran $(P=0.002)$ even though the gap between the scores are not relatively large (Table 4$)$. 
Table 4. Comparison of sensory attributes of FHM with those of commercial yoghurt drink. (20 panelists) (mean $\pm \mathrm{sd})$

\begin{tabular}{lccc}
\hline Attributes & Ayran & FHM & Level of significance \\
\hline Color & $4.50 \pm 0.41$ & $3.56 \pm 0.40$ & $*(P=0.047)$ \\
Taste & $4.10 \pm 0.95$ & $4.02 \pm 0.65$ & $(P=0.906)$ \\
Aroma & $0.62 \pm 0.21$ & $4.41 \pm 0.79$ & $*(P=0.001)$ \\
Consistency & $3.70 \pm 0.44$ & $2.53 \pm 0.40$ & $*(P=0.027)$ \\
Typical yoghurt odor & $4.40 \pm 0.52$ & $3.27 \pm 0.32$ & $*(P=0.033)$ \\
Acidity & $3.65 \pm 0.41$ & $3.63 \pm 0.13$ & $(P=0.960)$ \\
Mouthfeel & $3.95 \pm 0.05$ & $3.73 \pm 0.32$ & $(P=0.313)$ \\
Overall acceptability & $4.20 \pm 0.10$ & $3.60 \pm 1.10$ & $*(P=0.002)$ \\
\hline
\end{tabular}

FHM: fermented hazelnut milk, * significantly different $(P<0.05)$

\section{CONCLUSION}

Fermented hazelnut milk by using yogurt starter culture including Lactobacillus delbrueckii subsp. bulgaricus and Streptococcus thermophilus strains has been successfully produced and its chemical, physico-chemical, rheological and sensorial attributes were analysed. The results of this study showed that FHM might be considered a novel fermented product with potential healthpromoting properties, suitable for a wide range of consumer groups, such as vegetarians and the ones prone to lactose containing products or people allergic to animal proteins. In addition, the fatty acid distribution of the beverage implies better health-promoting nutritional properties than the animal based milk produtcs. The overall appearance of the fermented hazelnut milk was good and palatable. Although the sensory characteristic might require further research, this work underlines the technical feasibility and makes one step further to produce an alternative fermented drink, rich of nutritive components.

\section{ACKNOWLEDGEMENTS}

This work was supported by the Scientific and Technological Research Council of Turkey (TÜBİTAK) under 2209B Program (grant number 1139B411503016). Valuable contribution from Hale Nur Kara is gratefully acknowledged.

\section{REFERENCES}

Alasalvar C, Shahidi F, Liyanapathirana CM, Ohshima T. (2003). Turkish Tombul Hazelnut ( Corylus avellana L.). 1. Compositional Characteristics. J Agric Food Chem 51:3790-3796. doi: $10.1021 /$ jf0212385
Al-nabulsi A, Shaker R, Osaili T, Al-taani M, Olaimat A, Awaisheh S, Abushelaibi A, Holley R. (2014). Sensory Evaluation of Flavored Soy MilkBased Yogurt: A Comparison between Jordanian and Malaysian Consumers. J Food Sci Eng 4:27-35.

AOAC (2000). Official Methods of Analysis of AOAC International. Assoc Off Anal Chem Int Method ce 2-66. doi: $10.3109 / 15563657608988149$

AOCS (2009). Determination of cis-, trans-, Saturated, Monounsaturated and Polyunsaturated Fatty Acids in Vegetable or Non-Ruminant Animal Oils and Fats by Capillary GLC (Ce 1h05). In: Official Methods and Recommended Practices of the AOCS. p Ce 1h-05

Ashraf R, Shah NP. (2011). Selective and differential enumerations of Lactobacillus delbrueckii subsp. bulgaricus, Streptococcus thermophilus, Lactobacillus acidophilus, Lactobacillus casei and Bifidobacterium spp. in yoghurt - A review. Int. J. Food Microbiol. 149:94-208.

Augusto PED, Cristianini M, Ibarz A. (2012). Effect of temperature on dynamic and steadystate shear rheological properties of siriguela (Spondias purpurea L.) pulp. J Food Eng 108:283289. doi: 10.1016/j.jfoodeng.2011.08.015

Bernat N, Chafer M, Chiralt A, GonzálezMartínez C. (2014). Hazelnut milk fermentation using probiotic Lactobacillus rbamnosus GG and inulin. Int J Food Sci Technol 49:2553-2562. doi: 10.1111/ijfs.12585

Bernat N, Cháfer M, Rodríguez-García J, Chiralt A, González-Martínez C. (2015). Effect of high 
pressure homogenisation and heat treatment on physical properties and stability of almond and hazelnut milks. LWT - Food Sci Technol 62:488496. doi: 10.1016/j.lwt.2014.10.045

Ertugay MF, Şengül M, Şengül M. (2004). Effect of ultrasound treatment on milk homogenisation and particle size distribution of fat. Turkish J Vet Anim Sci 28:303-308.

Ghoddusi HB, Robinson RK. (1996). Enumeration of starter cultures in fermented milks. J Dairy Res 63:151-158. doi: 10.1017/S0022029900031629

Gursoy O, Yilmaz Y, Gokce O, Ertan K. (2016). Effect of ultrasound power on physicochemical and rheological properties of yoghurt drink produced with thermosonicated milk. Emirates $J$ Food Agric 28:235-241. doi: 10.9755/ejfa.2015-09719

He S, Hekmat S. (2015). Sensory Evaluation of Non-Dairy Probiotic Beverages. J Food Res 4:186192. doi: http://dx.doi.org/10.5539/jfr.v4n1p186

Hongyu W, Hulbert GJ, Mount JR. (2000). Effects of ultrasound on milk homogenization and fermentation with yogurt starter. Innov Food Sci Emerg Technol 1:211-218. doi: 10.1016/S14668564(00)00020-5

Ilyasoğlu H, Yilmaz F, Burnaz NA, Baltaci C. (2015). Preliminary assessment of a yoghurt-like product manufactured from hazelnut slurry: Study using response surface methodology. LWT - Food Sci Technol 62:497-505. doi: 10.1016/j.lwt.2014.06.023

Janhøj T, Bom Frøst M, Ipsen R. (2008). Sensory and rheological characterization of acidified milk drinks. Food Hydrocoll 22:798-806. doi: 10.1016/j.foodhyd.2007.03.006

Jeske S, Zannini E, Arendt EK. (2017). Evaluation of Physicochemical and Glycaemic Properties of Commercial Plant-Based Milk Substitutes. Plant Foods Hum Nutr 72:26-33. doi: 10.1007/s11130-016-0583-0

Koksoy A, Kilic M. (2003). Effects of water and salt level on rheological properties of ayran, a
Turkish yoghurt drink. Int Dairy J13:835-839. doi: 10.1016/S0958-6946(03)00103-1

Kök MS. (2010). Characterization of Galactomannan Stabilised Yogurt Drink Using Dynamic Rheology. Int J Food Prop 13:209-220. doi: 10.1080/10942910903115095

Köksal AI, Artik N, Şimşek A, Güneş N. (2006). Nutrient composition of hazelnut (Corylus avellana L.) varieties cultivated in Turkey. Food Chem 99:509-515.

10.1016/j.foodchem.2005.08.013

Lainas K, Alasalvar C, Bolling BW. (2016). Effects of roasting on proanthocyanidin contents of Turkish Tombul hazelnut and its skin. J Funct Foods 23:647-653. doi: 10.1016/j.jff.2016.03.029

Lucey JA, Tamehana M, Singh H, Munro PA. (1999). Stability of model acid milk beverage: effect of pectin concentration, storage temperature and milk heat treatment. $J$ Texture Stud 30:305-318. doi: 10.1111/j.17454603.1999.tb00219.x

McDorman TL (2009) Context and Background. In: Salt Water Neighbors. Oxford University Press, pp 9-45

Muñoz J, Rincón F, Carmen Alfaro M, Zapata I, Fuente J, Beltrán O, León de Pinto G. (2007). Rheological properties and surface tension of Acacia tortuosa gum exudate aqueous dispersions. Carbohydr Polym 70:198-205. doi: 10.1016/j.carbpol.2007.03.018

O'Sullivan J, Beevers J, Park M, Greenwood R, Norton I. (2015). Comparative assessment of the effect of ultrasound treatment on protein functionality pre- and post-emulsification. Colloids Surfaces A Physicochem Eng Asp 484:89-98. doi: 10.1016/j.colsurfa.2015.07.065

Özünlü BT, Koçak C. (2010). The effect of different heat treatments of milk on quality of Ayran. GID A - J Food 35:355-362.

Pleissner D, Demichelis F, Mariano S, Fiore S, Navarro Gutiérrez IM, Schneider R, Venus J. (2016). Direct production of lactic acid based on simultaneous saccharification and fermentation of mixed restaurant food waste. J Clean Prod 143:615-623. doi: 10.1016/j.jclepro.2016.12.065 
Ramchandran L, Shah NP. (2009). Effect of exopolysaccharides and inulin on the proteolytic, angiotensin-I-converting enzyme- and $\alpha$ glucosidase-inhibitory activities as well as on textural and rheological properties of low-fat yogurt during refrigerated storage. Dairy $S_{c i}$ Technol 89:583-600. doi: 10.1051/dst/2009039

Ross-Murphy SB. (1984). Rheological methods. In: Chan HW-S (ed) Biophysical methods in food research. Blackwell, Palo Alto, CA, USA, pp 195290

Routray W, Mishra HN. (2012). Sensory evaluation of different drinks formulated from dahi (Indian Yogurt) powder using fuzzy logic. $J$ Food Process Preserv 36:1-10. doi: 10.1111/j.17454549.2011.00545. $\mathrm{x}$

Sharoba AM, Senge B, El-Mansy HA, Bahlol H, Blochwitz R. (2005). Chemical, sensory and rheological properties of some commercial German and Egyptian tomato ketchups. Eur Food Res Technol 220:142-151. doi: 10.1007/s00217004-0981-7

Shirkhani M, Madadlou A, Khosrowshahi A. (2015). Enzymatic Modification to Stabilize the Fermented Milk Drink, Doogh. J Texture Stud 46:22-33. doi: $10.1111 /$ jtxs. 12107
Simsek A, Aykut O. (2007). Evaluation of the microelement profile of Turkish hazelnut (Corylus avellana L.) varieties for human nutrition and health. Int J Food Sci Nutr 58:677-688. doi: 10.1080/09637480701403202

Steffe, J.F. (1996). Rheological Methods in Food Process Engineering, second edition (second printing). Freeman Press, East Lansing, MI, USA.

Wijesinha R, Burlingame B. (2013). Milk and dairy product composition. In: Muehlhoff E, Bennett A, McMahon D (eds) Milk and Dairy Products in Human nutrition. FAO, pp 41-102

Yasmin A, Butt MS, Yasin M, Qaisrani TB. (2015). Compositional analysis of developed whey based fructooligosaccharides supplemented lowcalorie drink. J Food Sci Technol 52:1849-1856. doi: 10.1007/s13197-014-1535-z

Zhou, Z. (2018). Effects of dried apple peel powder on the rheological and sensory properties of drinking yogurt (MSc dissertation). The University of Guelph, Guelph, Ontario, Canada. 